\title{
1 Corrigenda, vol.1
}

P. 25

\begin{tabular}{llllllll}
\hline$*$ & X192b & - & & - & - & $X$ & $X$ \\
\hline
\end{tabular}

* Pesiqta Rabbati 37: Isa 61:10f. - Haftarah reading for the seventh Sabbath of Consolation. Tosafot bMeg 31b, s.v. שאר.

p. 273 Kings $>$ Kgs

p. 303 Korḥa> Qorḥa

p. 585 [Job 26:5]> (Job 26:9)

p. 617 R. Judah> R. Yehudah 
